\title{
EFFECT OF TYPE OF VEGETATION, MOISTURE AND PH OF SOIL ON AVAILABIITY OF DIFFERENT ECOLOGICAL GROUPS OF EARTHORM
}

\author{
Neeru Agrawal and Jaya Chandraker \\ Dett.of Zoology, Govt.V.Y.T.Auto College,Durg (C.G.) \\ E.Mail: neeru.bhilai@gmail.com
}

\begin{abstract}
Earthworms are important soil macrofauna that have profound effects on ecosystems. They have attracted a lot of interest due to their beneficial effects, especially in agriculture (Brown 1995,Dechaine et al 2005,Larink et al 2001). Earthworms occur in most temperate soil \& many tropical soils and they play an important role in maintaining the productivity of our soil. Epigeic, Endogeic \& Enecic are three broad ecological groups of earthworms \&. Each group tends to affect the forest differently. More than 1000 different earthworm species can be placed into one of three groups. In the present study sampling of soil near different vegetation sites was done to observe the effect of moisture, $\mathrm{pH}$ and type of vegetation on availability of different ecological groups of earthworm. Epigeic form of earthworms were observed in maximum while anecic forms in less number. No endogeic forms were reported. Overall availability of earthworms at various sites studied mainly affected by differences in moisture $\& \mathrm{pH}$ of soil.
\end{abstract}

Keywords: Epigeic, Endogeic \& Enecic

\section{Introduction:}

There are three broad ecological groups of earthworms distinguished by both colour \& size:(1)Epigeic earthworm :Litter \& Surface Dwelling species that live \& feed only at the surface, sometimes only in the litter layer with $1-7 \mathrm{~cm}$ long and pigmented body. Pigmentation may provide protection from predators \& UV rays,.(2)Endogeic Earthworm :Soil Dwelling species Earthworms that live and feed in the mineral soil, rather than at the surface, are called endogeic . Adult endogeic earthworms can range from small to large in size $(2-12 \mathrm{~cm}$ long), depending on the species, but are identified by their lack of skin pigmentation.3) Enecic earthworm :Deep Burrowing species that burrow very deeply (down to 2 meters) but feed on fresh surface litter (Great Lakes Worm Watch). Anecic species are the largest species of earthworms. They are darkly coloured at the head end (red or brown) and have paler tails. They have the potential to eat huge amount of litter and as a result can have big effects on the forest floor when they invade.

Earthworm feeding behaviour, burrowing and casting are vital in nutrient cycling \& decomposing regulation (Brown 1995,Dechaine et al 2005,Larink et al 2001). Earthworm ecological groups have variable effects on the soil physical, chemical \& biological properties (Lee, 1985). Soil moisture content may affect the biomass of earthworm because water constitutes $75-90 \%$ of their body weight (Grant, 1995). Moisture is one of the key factors affecting the survival of all earthworm species (Bohlen et al 1995,Edwards \& Bohlen 1996). Several studies have recorded a decline in earthworm population in response to dry season (Bohlen et al 1995, Gonzalez et al 1996, Najar \& Khan,2011). Earthworms are very sensitive to soil pH (Edwards \& Bohlen,1996) and soil with low $\mathrm{pH}$ limit earthworm survival $\&$ activity (Springett \& Syers, 1984). Acidic soil are characterized by higher availability of metal ions (Brady, 1984) that cause unfavorable conditions for earthworms. A survey conducted in a tropical agro ecosystem revealed that earthworms preferred to inhabit soil with $\mathrm{pH}$ ranging from 6.1-6.8 (Fragoso et al,1999).Similar observation were also reported by Shakir \& Dindal (1997) and Nair etal,2005, who found higher number of earthworms in areas with $\mathrm{pH}$ near neutral (6.87.1). According to Tian etal (2002) tree plantation may influence earthworm abundance by altering the physiochemical properties of soil i.e. temperature, moisture regime, $\mathrm{pH}$ of soil, organic content, litter inputs etc. In the present study sampling of soil at various sites selected on the basis of type of vegetation was done to observe the effect of moisture \& $\mathrm{pH}$ on availability of different ecological groups of earthworm up to depth of 2-3 inches.

\section{Methodology}

Survey for this project work was conducted from the month of December to February to avoid drying of soil. Various sites near different types of plant like Lemon, Papaya, Hibiscus, Neem \& Tulsi were selected. Area of about 1 meter diameter around each tree was sampled. Soil samples from about 3 inches below the ground level from each site were collected for recording pH\& moisture content of soil. Presence of earthworm was observed at every sampling sites 
by looking them on the surface of the soil, in leaf litter and by digging the area of about 3 inches below the ground level. Earthworms that emerged from the ground were hand- picked \& bathed in water and preserved in $4 \%$ formalin OBSERVATION AND REULTS:

Table:1. Ecological categories of earthworms observed with reference to several morphological \& Ecological parameters at various vegetation sites

\begin{tabular}{|c|c|c|c|c|c|c|c|c|}
\hline $\begin{array}{l}\text { Seleced } \\
\text { plant }\end{array}$ & $\begin{array}{c}\text { Ecological } \\
\text { Category }\end{array}$ & $\begin{array}{c}\text { Frequency } \\
\text { Of } \\
\text { observation }\end{array}$ & $\begin{array}{l}\text { number } \\
\text { observed }\end{array}$ & $\begin{array}{c}\text { Collected } \\
\text { From }\end{array}$ & $\begin{array}{c}\text { Size } \\
\text { Ranges }\end{array}$ & $\begin{array}{l}\text { Colour of } \\
\text { earthworm }\end{array}$ & $\begin{array}{l}\text { Average } \\
\text { pH of } \\
\text { soil }\end{array}$ & $\begin{array}{c}\text { Average } \\
\text { Moisture } \\
\text { of soil }\end{array}$ \\
\hline Lemon & Epigeic & All four sites & $\begin{array}{c}\text { Observed in } \\
\text { bunches of } \\
\text { more than } \\
10\end{array}$ & $\begin{array}{l}\text { 0-10cm from } \\
\text { soil surface }\end{array}$ & $\begin{array}{c}6.1- \\
6.5 \mathrm{~cm}\end{array}$ & $\begin{array}{l}\text { Reddish- } \\
\text { brown }\end{array}$ & 7.4 & $24.75 \%$ \\
\hline Hibiscus & Epigeic & $\begin{array}{l}\text { Only at one } \\
\text { site }\end{array}$ & $\begin{array}{c}\text { In bunch of } \\
\text { more than } \\
17\end{array}$ & $\begin{array}{l}\text { 0-10cm from } \\
\text { soil surface }\end{array}$ & $\begin{array}{c}6.1- \\
6.5 \mathrm{~cm}\end{array}$ & $\begin{array}{l}\text { Reddish- } \\
\text { brown }\end{array}$ & 7.65 & $19.3 \%$ \\
\hline Papaya & Anecic & At two sites & $\begin{array}{c}\text { One on each } \\
\text { Side }\end{array}$ & Surface litter & $9.5 \mathrm{~cm}$ & $\begin{array}{l}\text { Head-Red, } \\
\text { Tail-paler }\end{array}$ & 8.4 & 11.2 \\
\hline Neem & - & Nil & - & - & - & - & 5.7 & 8.4 \\
\hline Tulsi & - & Nil & - & - & - & - & 8.5 & 15.8 \\
\hline
\end{tabular}

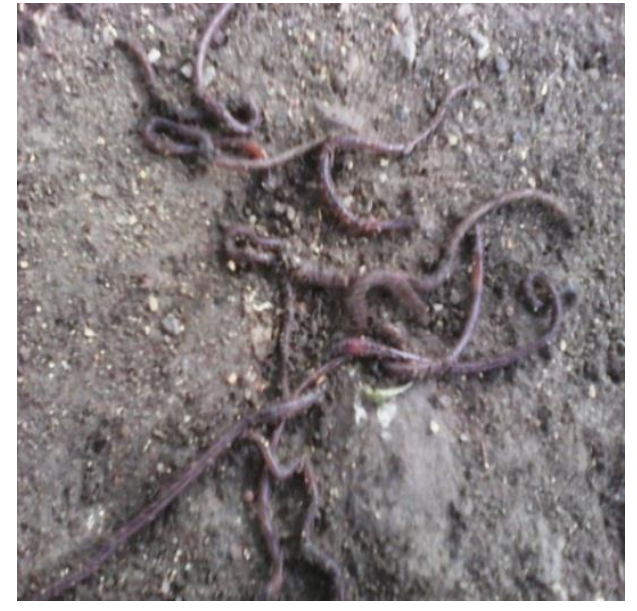

Fig.1:Bunch of Epigeic earthworms in soil near Lemon tree before being transported to be laboratory. Size, colour and morphology of earthworm were observed. For conservation of biodiversity minimum number of worms (2-3) were preserved and others were released back to soil.

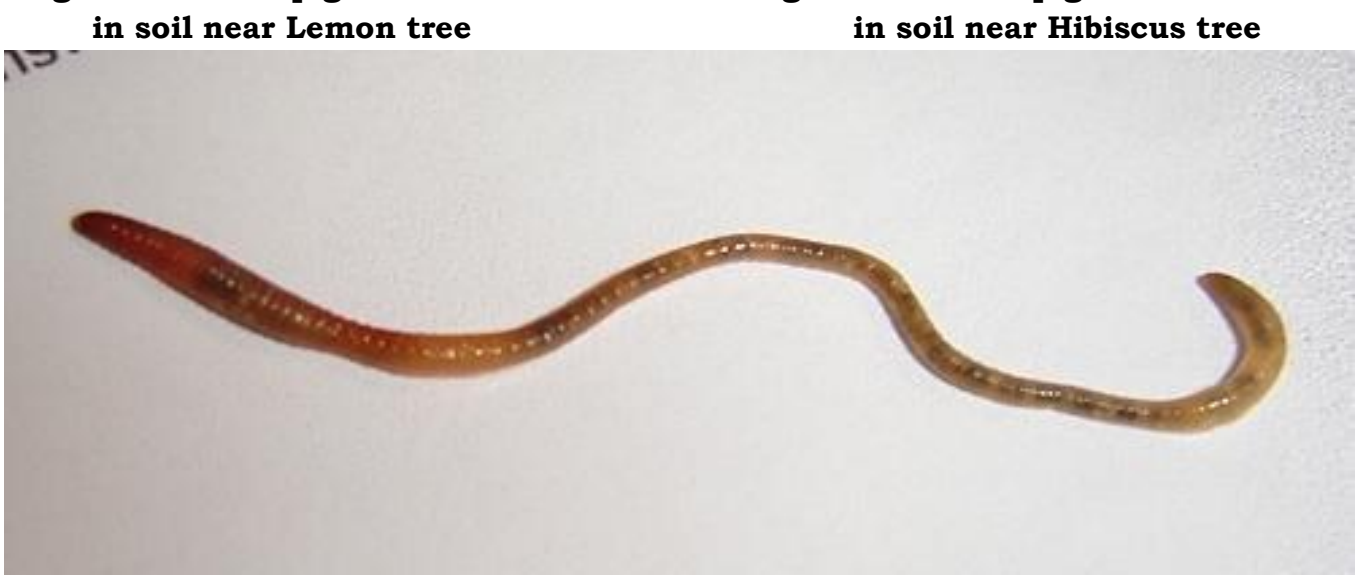

Fig.3: Anecic form of Earthorm in soil near Papaya tree

\section{Discussion}

Present study revealed that most of the epigeic form of earthworms were observed in soil where the $\mathrm{pH}$ of soil is almost near neutral( Shakir \& Dindal,1997,Fragoso etal.1999 and Nair etal., 2005). According to Bohlen et al 1995,

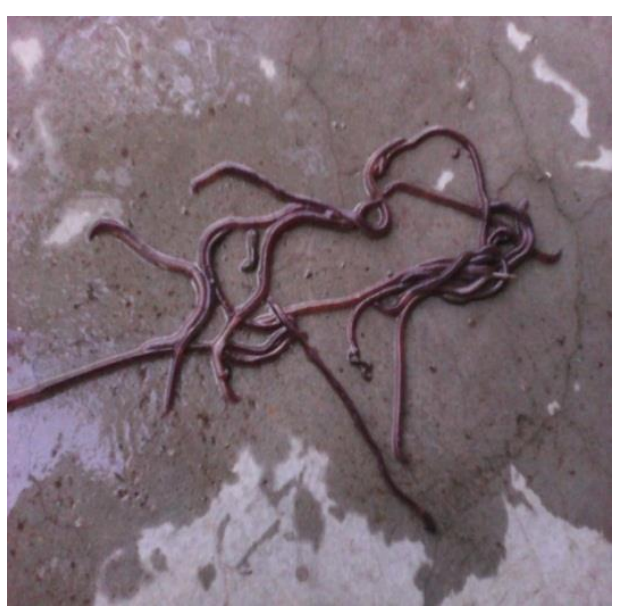

Fig.2: Bunch of Epigeic earthworms in soil near Hibiscus tree 
Anecic earthworm species was observed in very less number at soil surface near Papaya tree. Its presence at surface may be due to its feeding habit because it was found deeply down to 2 meters but feed on surface litter (Great Lakes worm watch).It was recorded that soil with low $\mathrm{pH}$ limit earthworm survival and activity (Springett \& Syers, 1984).Complete absence of earthworm in soil near Neem tree may be due to acidic nature of soil because in acidic soil higher availability of metal ions causes unfavorable conditions for earthworm (Brady, 1984). Not a single earthworm is reported near Tulsi which may be due to alkaline nature of soil. Finally it can be inferred that Lemon sites are largely dominated by epigeic category of earthworm. This category experienced mean moisture $24.75 \%$ and $\mathrm{pH} 7.4$. This moisture content is neither very high nor low but is in moderate level. Similarly $\mathrm{pH}$ of soil which is near to neutral is very much favorable for the survival $\&$ activity of earthworms.

\section{Conclusion}

In the present work, various sites were selected but earthworms are reported in very few sites. This decrease may be due to several ecological factors such as temperature, available organic matter, moisture, $\mathrm{pH}$ etc. The direct or indirect influence of human activities like use of chemicals on soil, use of machinery, deforestation, artificial irrigation throughout the year etc. are the major cause for changes in various ecological factors that may adversely affect earthworm population in soil.

\section{Bibliography}

- Bohlen,P.J.,Edwards,W.M.\&Edwards,C. A.(1995):Earhworm community structure and diversity in experimental agricultural watersheds in North-eastern Ohio. Plant and Soil 170: 233-239.

- Brady,N.C.(1984): The Nature and Properties of Soils. 9thedn.,Collier McMillan, London.

- $\quad$ Brown,G.G.(1995): How do earthworms affect microfloral and faunal community diversity? Plant and Soil 170: 209-231.

- Dechaine,J.,Ruan,H.H.,Leon,Y.S.,\&Zou, X.M.(2005):Correlation between earthworms and plant litter decomposition in a tropical wet forest of Puerto Rico. Pedobiologia 49: 601-607.

- $\quad$ Edwards,C.A.\&Bohlen,P.J.(1996):Biolog $\mathrm{y}$ and Ecology of earthworms. Chapman and Hall, London.

- $\quad$ Fragoso,C.,Kanyonyo,J.,Moreno,A.,Sena pati,B.K.,Blanchart,E.\& Rodriguez,C.(1999): A survey of tropical earthworms: taxonomy, biogeography and environmental plasticity. Pp. 1-26. In: P. Lavelle, L. Brussaard \& P. F. Hendrix (edn). Earthworm Management in Tropical Agroecosystem. CAB International, Wallingford, UK.

- $\quad$ Gonzalez,G.,Zou,X.\&Borges,S.(1996):Ea rthworm abundance and species composition in abandoned tropical croplands: comparison of tree plantation and secondary forests. Pedobiologia 40: 385-391.

- Grant,W.C.(1995):Studies on moisture relationship in earthworms. Ecology 36: 400407.

-

Larink,O.,Werner,D.,Langmaack,M.\&.Schrader,S .(2001):Regeneration of compacted soil aggregates by earthworm activity. Biology and Fertility of Soils 33: 395-401.

- Lee,K.E.(1985): Earthworms their Ecology and Relationship with Soils and Land Use. Academic press, Sydney.

- $\quad$ Nair,G.A.,Youssef,K.,El-

Mariami,M.A.,Filogh,A.M.,\&Briones,M.J.I.

(2005): Occurrence and density of earthworms in relation to soil factors in Benghazi, Libya. Africa Journal of Ecology 34: 150-154.

- $\quad$ Najar,I.S.\&Khan,A.B.(2011):Earthworm communities of Kashmir Valley, India. Tropical Ecology 52: 151-162.

- Shakir,S.H.\& Dindal, D.L.(1997): Density and biomass of earthworm in forest and herbaceous microecosystem in central New York, North America. Soil Biology and Biochemistry 29: 275-285.

- $\quad$ Springett, J. A. \& Syers, J.K.( 1984): Effect of $\mathrm{pH}$ and calcium content of soil on earthworm and cast production in the laboratory. Soil Biology and Biochemistry 16: 185-189.

- Tian,G.,Olimah,J.A.,Adeoye,G.O.\&

Kang, B. T.(2002): Regeneration of earthworm population in a degraded soil by natural and planted fallows underhumid tropical conditions. Soil Science Society of America Journal 64: 222228.

-

www.nrri.umn.edu/worms/identification/ecolog y_groups.html Great Lakes Worm Watch, Earthworms by Ecological Group. A Guide to Earthworms You'll Find in The Great Lakes Region. 